\title{
リチウムタンタレートを用いた小型バイモルフ振動子の 共振周波数調整*
}

\author{
明石照久 $^{* *}$ 大津満雄 $^{* * *}$ 長崎 正 $^{* * *}$ 角田莞爾 $^{+}$ \\ Adjustment of the Resonant Frequencies of a Micro Bimorph-Type Resonator Made of Lithium Tantalate Piezoelectric Material
}

Teruhisa AKASHI, Mitsuo OHTSU, Tadashi NAGASAKI and Kanji KAKUTA

\begin{abstract}
A micro bimorph-type resonator, $10 \mathrm{~mm}$ in length, $1.014 \mathrm{~mm}$ in thickness and $0.97 \mathrm{~mm}$ in width, made of 130-degreesrotated Y-cut lithium tantalate with a large piezoelectric effect and a large Q-factor was developed for use in an angular rate sensor. For a sensor with high sensitivity, the resonant frequency of the driving-mode vibration must correspond to that of the detecting-mode vibration. Therefore, we experimentally adjusted the two resonant frequencies by YAG-laser trimming. This experiment showed that the difference between the two resonant frequencies was $1580 \mathrm{~Hz}$ before the adjustment by the YAGlaser trimming but decreased to $5 \mathrm{~Hz}$, at the rate of approximately $18 \mathrm{~Hz}$ per microgram of trimmed tantalate, after it. Moreover, it was found that the resonator after the adjustment can vibrate, at the same resonant frequency, without mechanical coupling not only in the driving-mode but also in the detecting-mode. It is thus concluded that such desirable vibration characteristics make the resonator suitable for the sensing element of an angular rate sensor.
\end{abstract}

Key words: bimorph-type resonator, lithium tantalate, resonant frequency, YAG-laser trimming, angular rate sensor

\section{1. 腥 言}

リチウムタンタレート" $\left(\mathrm{LiTaO}_{3} ; \mathrm{LT}\right)$ は, 昨今の携帯電話の 普及により，SAW(Surface Acoustic Wave)フィルタとして大き く需要を伸ばしている単結晶の圧電枋料である. 特に, リチウ ムタンタレートの $130^{\circ}$ 回転 Y 板は, 面内でたわむ振動モード とそれに垂直な振動モードに対して大きな電気機械結合係数を 持つ. さらに, その機械的 $\mathrm{Q}$ 值は大きく, 温度係数も小さいと いう特長を持つ2) 3 》。

このような特長を生かし, 振動式ジャイロセンサの振動子と してリチウムタンタレート製の小型音叉が適用されている ${ }^{314}$. 振動式ジャイロセンサとは, 印加角速度によって発生するコリ オリカから，振動子に加わる角速度を検出するセンサのことで ある.この振動式ジャイロセンサでは，振動子のお互いに直交 する二つの振動モードが角速度を検出するために利用される. 二つの振動モードのうち, 一つは角速度が印加されない定常状 態において振動子が振動する駆動モードであり，もう一つはコ リオリカが発生する軸方向に振動子が振動する検出モードであ る. 近年, 振動式ジャイロセンサの研究開発は盛んに行われ， 特に単結晶シリコンを用いたバルクまたはサーフェスマイクロ

* 原稿受付 平成 13 年 3 月 26 日

** 正会貝 (株) 日立製作所 機械研究所 (土浦市神立町 502)

****（株）日立メディアエレクトロニクス（横浜市戸塚区吉田町 501）

+ (株) 日立製作所 デジタルメディアシステム事業部 (東京都巷区西新橋 2 . $15-12)$
マシニングによる小型の振動式ジャイロセンサが数多く試作さ れ，角速度の検出感度評価が行われている ${ }^{51-7 ! . ~}$

通常，振動子は駆動モードにおいて振動軸に沿って振動する ことが理想とされる。しかし，奏際の振動方向は，振動子の非 対称性 ${ }^{8)}$ やメカカルカップリング ${ }^{91}$ の影響によって, 理想の 振動方向に対して角度 $\theta$ 傾いて振動することがある ${ }^{10)}$.この振 動角度 $\theta$ が大きい場合，コリオリカのオフセット量が大きくな るため, 印加角速度を正確に検出することが困難となる，その ため, 駆動モードにおいて振動角度 $\theta$ はできるだけ小さいこと が望ま机る。

一方, 駆動モードの共振周波数すなわち振動軸方向の共振周 波数と, 検出モードの共振周波数すなわちコリオリカが発生す る軸方向の共振周波数とを一致させることで, 振動式ジャイロ センサの角速度検出感度は最大となる ${ }^{9}$ 。そのため, 振動軸方 向とコリオリカが発生する軸方向との共振周波数が一致してい る振動子が望まれる。

つまり，振動式ジャイロセンサの高感度化のために，振動子 は, 振動角度 $\theta$ が小さいことと振動軸方向とコリオリカが発生 する軸方向との共振周波数が一致していることとの二項目を満 足する必要がある.

我々はリチウムタンタレートを用いた振動式ジャイロセンサ を開発するために, $130^{\circ}$ 回転 Y 板のリチウムタンタレートを 用いたバイモルフ構造の両持ち振動はりを新たに試作した．前 報 ${ }^{10)}$ では, 振動角度 $\theta$ が小さくさらに共振周波数差が小さい振 動式ジャイロセンサの振動子として適切な振動特性を備える振 動はりの形状を明らかにした，本報では，その振動はりの駆動 モードの共振周波数と検出モードの共振周波数とを一致させる ために, YAG レーザを用いた共振周波数調整について報告する. 
Table 1 Specifications of LT wafers

\begin{tabular}{l|l} 
Diameter & 2 inch $(50 \pm 0.5 \mathrm{~mm})$ \\
Thickness & $500 \pm 25 \mu \mathrm{m}$ \\
Orientation & 130 deg. $\mathrm{Y} \pm 0.2 \mathrm{deg}$. \\
Process & Czochralski method \\
O.F. direction & $\mathrm{X}$-axis $\pm 0.2 \mathrm{deg}$. \\
Finish (Front side) & Polished $\left(\mathrm{R}_{\mathrm{y}}: 1-3 \mu \mathrm{m}\right)$ \\
Finish (Back side) & Polished $\left(\mathrm{R}_{\mathrm{y}}: 1-3 \mu \mathrm{m}\right)$ \\
Flatness & $<30 \mu \mathrm{m}$ \\
\hline
\end{tabular}

1. Assembling

Bonding resonator and suspension Arm of suspension

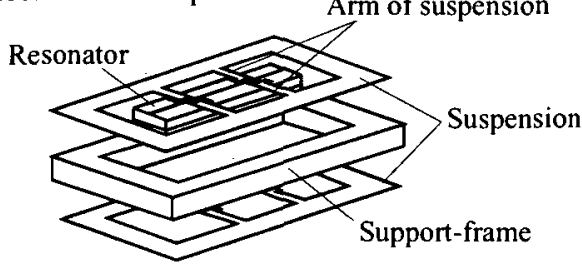

2. Laser cutting

Separation of electrodes

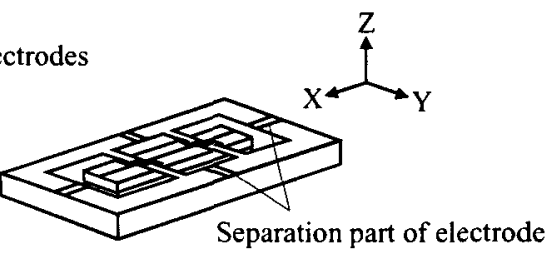

3. Laser trimming

Ajustment of resonant frequencies

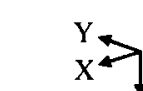

Thin-film electrode

of backside

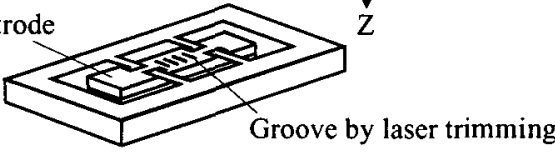

Fig.1 Fabrication process of the LT resonator

\section{2. 実験 方 法}

\section{1 加エプロセス}

図1にバイモルフ構造で両持ち支持の振動はりを適用した LT 振動子の加工プロセスを示す，振動はりは，両面に $\mathrm{Au} / \mathrm{Pt} / \mathrm{Ti}$ 薄 膜を成膜した 2 枚のリチウムタンタレートウエハを分極方向が 互いに逆向きになるように接着し，ダイシングで切り出すこと により形成さ妃る.図 2 に振動はりの形状を示す. 振動はりは, 長さが $10 \mathrm{~mm}$, 幅が $0.97 \mathrm{~mm}$, 厚さが $1.014 \mathrm{~mm}$ である. 振動は りの表面中央部には電圧印加用の電極パターンが 2 か所, サ スペンションと接続用の電極パッドが 4 か所形成され，裹面に はパターンが形成されていない。このような振動はりとそれを 支持するサスペンションおよび固定枠とを組み立て，振動はり の電極とアームとの電気的接続を同時に行った(1.).ここで, サスペンションは自由境界における1次共振モードの節の位置 で振動はりを支持するだけでなく電気配線の役割を担う。次に， YAG レーザ装置を用い, サスペンションの一部を切断して振動 はりの電気的分離を行った（2.)．最後に，同じ YAGレーザ装 置を用いて振動はりの自面側の中央部をレーザトリミングし， 振動はりの共振周波数調整を行った（3.).なお，各薄膜の膜厚 は, Ti が $0.1 \mu \mathrm{m}, \mathrm{Pt}$ が $0.2 \mu \mathrm{m}, \mathrm{Au}$ が $0.5 \mu \mathrm{m}$ であり，リチウム タンタレートウエハには表1の仕様のウエ八を用いた。
Table 2 Conditions of the YAG-laser trimming

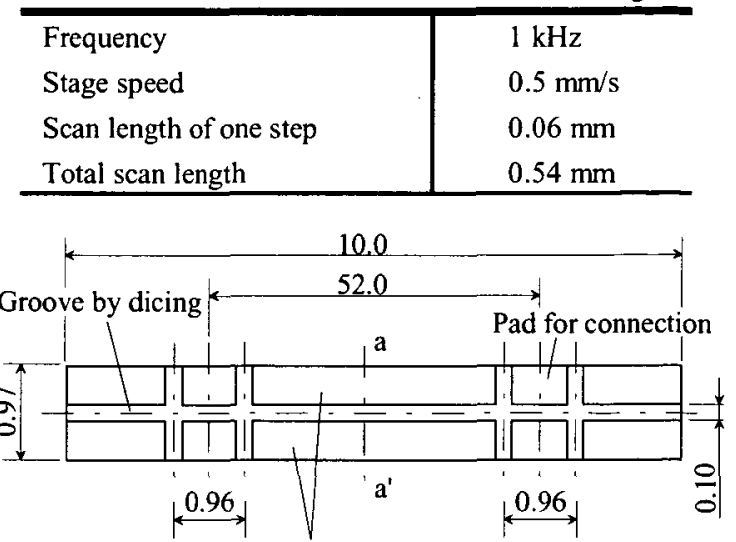

Thin-film electrode for applying voltage Upper electrode

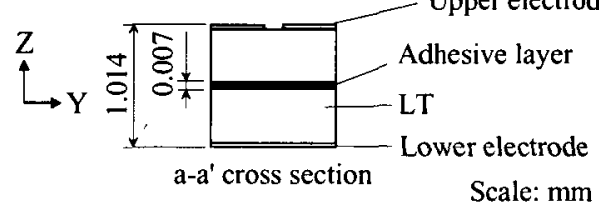

Fig.2 Schematic view of the LT resonator

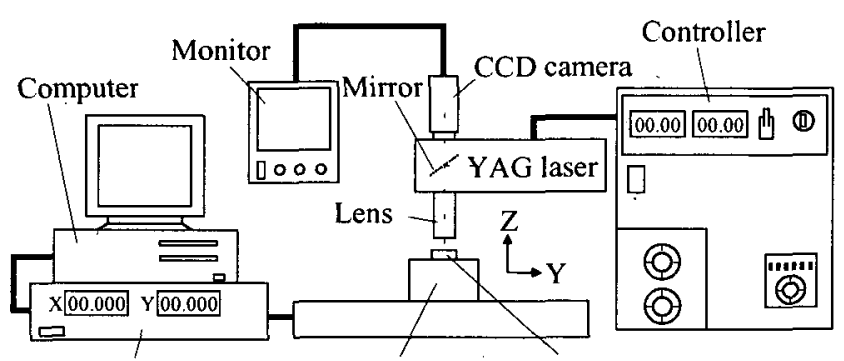

$\mathrm{X}-\mathrm{Y}$ stage controller $\mathrm{X}-\mathrm{Y}$ stage $\mathrm{LT}$ resonator

Fig.3 Schematic view of the YAG-laser trimming system

\section{2 レーザトリミング方法}

振動軸 ( $\mathrm{Z}$ 軸とする. 図 2 参照.) 方向とコリオリカが発生す る軸 ( $Y$ 軸とする.図 2 参照.) 方向との共振周波数を一致させる ために, YAG レーザ装置(Nd:YAG LASER SL116E Q-switch-type, NEC 製)を用いて振動はりのレーザトリミシグを行った。図 3 にYAGレーザ装置のシステム概略図を示す。このシステムは, レーザ出力およびパルス周波数を決定する出カコントローラ, YAG レーザ本体, 被加工対象物である振動はりを載せる X-Y 駆動ステージおよびステージを駆動させるステージコントロー ラ, CAD 図面を NCデータに変換しステージコントローラにデ 一タ転送するためのパソコン，振動はりを観察するための CCD カメラおよびモニタから構成される.レーザ光の周波数は 0一 $99 \mathrm{kHz}$ まで調整することができる。また，X軸方向および $\mathrm{Y}$ 軸 方向の位置決め精度は土0.01 $\mathrm{mm}$ 以下であり，移動速度は 0.01 - $1 \mathrm{~mm} / \mathrm{sec}$ の範囲で可変である.なお，レーザトリミングには 表 2 に示す条件を適用した.ここでのステップ送り長さとは, レーザを出力した状態でステージを移動させる距離掞よびレー ザを出力しない状態でステージを移動させる距離のことを言う. すなわち，レーザをパルス走査することによってレーザトリミ ングを行い，そのときのパルス幅が $0.06 \mathrm{~mm}$ であることを表す.

図 4 に示寸振動はりの裏面側にレーザトリミングを行った. 具体的には，振動はりの幅方向と平行に，振動はりの端から $0.215 \mathrm{~mm}$ の位置を起点として長さ $0.54 \mathrm{~mm}$ の位置までレーザト 


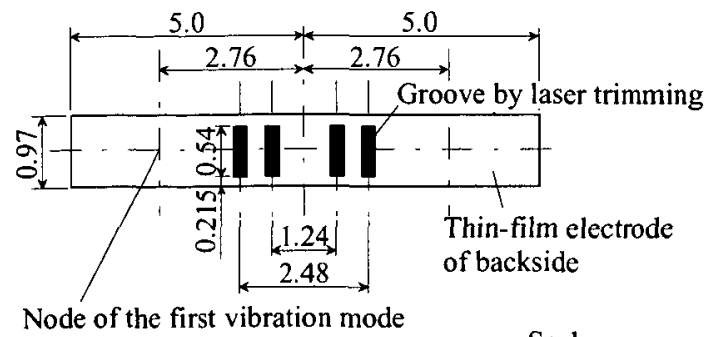

Scale: $\mathrm{mm}$

Fig.4 Position of the groove by the YAG-laser trimming

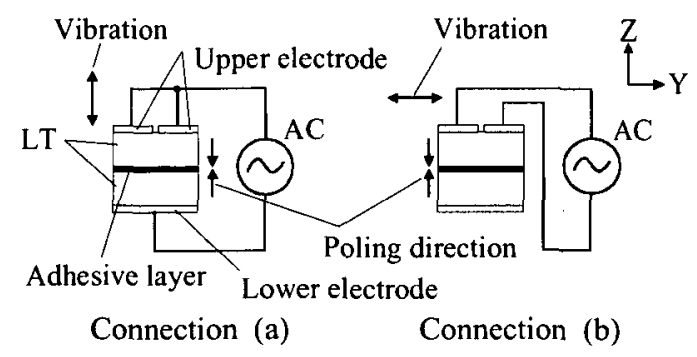

Fig.5 Schematic view of the electrical connection

リミングを行った。この場合のレーザトリミングによる溝は， 自由境界における 1 次共振モードの節で挟まれた範囲に形成さ れる.このように、レーザトリミング溝を中心線に対して対称 に形成し，共振周波数の調整を行った。

なお,レーザトリミング前後における振動はりの質量の測定 には, 電子天科(AT20, METTLER TOLEDO 製，分解能：2 $\mu \mathrm{g}$ ) を用いた。

\section{3 振動特性評価方法}

リチウムタンタレートは压電材料であるので, 共振点付近に おける振動はりの電気的等価回路は, LCRの直列共振回路に C を並列接続させた回路として表される クタンス， $\mathrm{C}$ は容量， $\mathrm{R}$ は電気抵抗とする，そのため，振動は りの共振周波数を電気的に測定することが可能である.そこで, インピーダンスアナライザ (4194A Impedance/Gain-Phase Analyzer, Yokogawa Hewlett Packard 製, 周波数分解能：1 Hz) を用いて，振動はりの共振周波数を電気的に測定した。

さらに, 振動はりの機械的な振動特性を 2 チャンネルのレーザ ドップラ振動計(以下 LDV と呼ぶ. Laser Vibrometer LV-1610, 小 野測器製) と FFT アナライザ(CF-5200 Multi-Purpose FFT Analyzer, 小野測器製, 周波数分解能: $0.25 \mathrm{~Hz}$ )とによって評価した ${ }^{10\}}$ ここ の評価において，振動はりを Z軸方向に振動させる場合には， 図 5 の結線(a)を用いて $1.0 \mathrm{Vp}-\mathrm{p}$ の交流電圧を振動はりに印加した。 一方, 振動はりを Y 軸方向に振動させる場合には, 図 5 の結線(b) を用いて $1.0 \mathrm{Vp}$-p の交流電圧を振動はりに印加した。

\section{3. 実釦結果および考察}

\section{1 振動はりの共振周波数調整精度}

レーザ出力と 1 回のレーザトリミングによる除去量すなわち レーザトリミング量との関係を調べた.その結果を図 6 に示す. このときの各レーザトリミング量は，振動はりにレーザトリミ ングによる溝を 10 か所以上形成した後に除去量を測定し，そ机 を平均して求めた值である。この結果，レーザ出力とレーザト リミング量との関係は比例関係にあることが分かった。レーザ 出力が大きいほどレーザトリミング量が大きい.ただし，レー

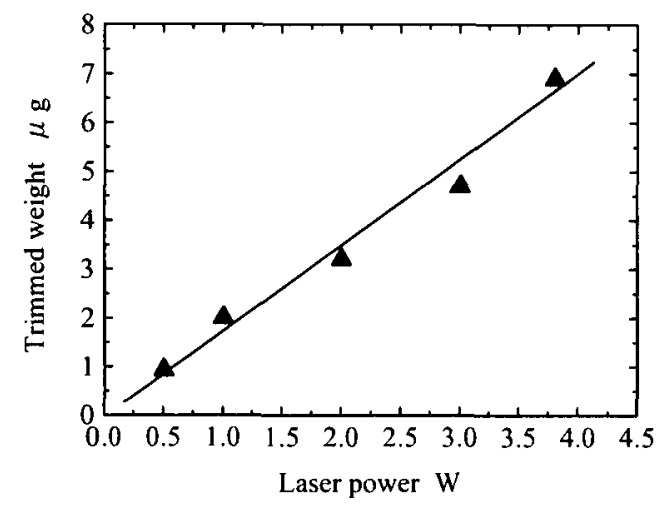

Fig.6 Trimmed weight as a function of laser power

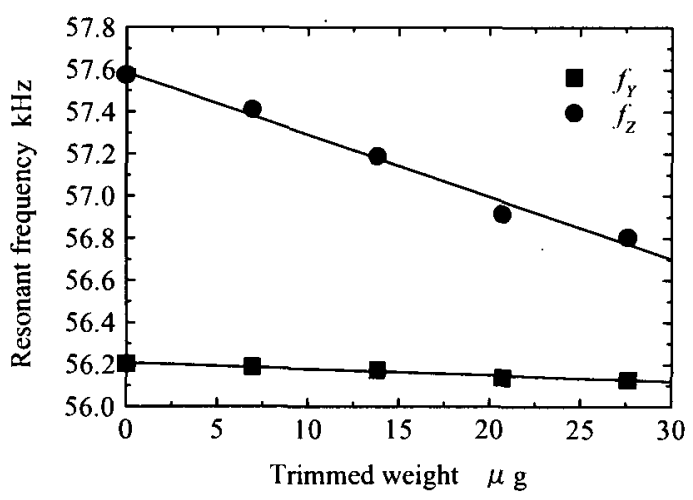

Fig.7 Resonant frequency as a function of trimmed weight

ザ出力が $3.8 \mathrm{~W}$ を超えるとき振動はりにクラックが発生した。

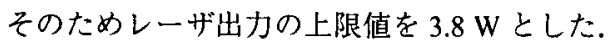

図 7 は YAG レーザの出力が $3.8 \mathrm{~W}$ のときの Y 軸および Z 軸 方向の共振周波数の変化を測定した結果である. 横軸はレーザ トリミング量を表し, 縦軸は振動はりの共振周波数を表す。た だし，このときのレーザトリミング量は，図6で得ら机た結果 を基に算出した值である。この結果，レーザトリミング量を増 加させるに従い, Z 軸方向の共振周波数はリニアに減少するが, $\mathrm{Y}$ 軸方向の共振周波数はほとんど変化しないことが分かった。 この場合のレーザトリミング量と Y 軸方向およびZ軸方向の共 振周波数との関係は次式で表すことができる.

$$
\begin{aligned}
& f_{Y}=-29.00 \times 10^{-4} w+56.21 \\
& f_{Z}=-29.49 \times 10^{-3} w+57.59
\end{aligned}
$$

ただし， $\mathrm{Y}$ 軸方向の共振周波数を $f_{Y}(\mathrm{kHz}), \mathrm{Z}$ 軸方向の共振 周波数を $f_{Z}(\mathrm{kHz})$ ，レーザトリミング量を $w(\mu \mathrm{g})$ とする.

式(2)より，レーザ出力が 3.8 W の場合, レーザトリミング量に 対する Z 軸方向の共振周波数変化率は $29.5 \mathrm{~Hz} / \mu \mathrm{g}$ であった. また， この場合のレーザトリミング量と共振周波数差との関係から, 共 振周波数差の变化率は $26.6 \mathrm{~Hz} / \mu \mathrm{g}$ であった. さらに, レーザ出力 が $0.5 \mathrm{~W}, 1.0 \mathrm{~W}$ の場合における共振周波数差の変化率を測定し

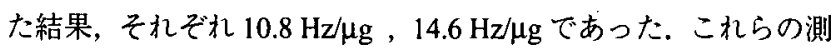
定結果より, 共振周波数差の变化率 $R_{f}(\mathrm{~Hz} / \mu \mathrm{g})$ はレーザ出力 $P(\mathrm{~W})$ の関数として次式で表すことができると考える.

$$
R_{f}=4.617 P+9.176
$$

式(3)より,レーザ出力が小さいほど微小な周波数調整が可能 


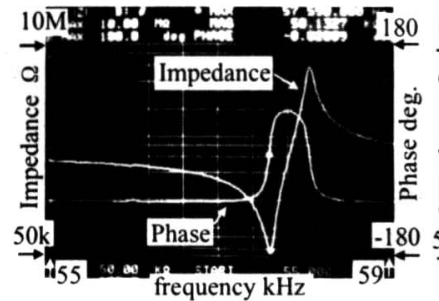

Connection (a)

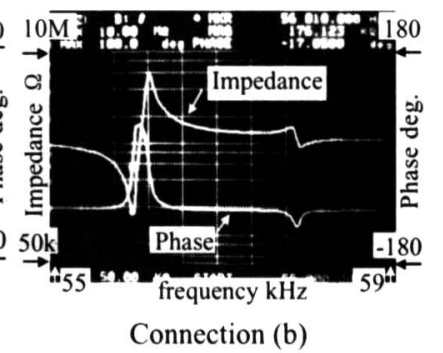

Connection (b)
Fig.8 Impedance characteristics of the LT resonator by impedance/gain-phase analyzer

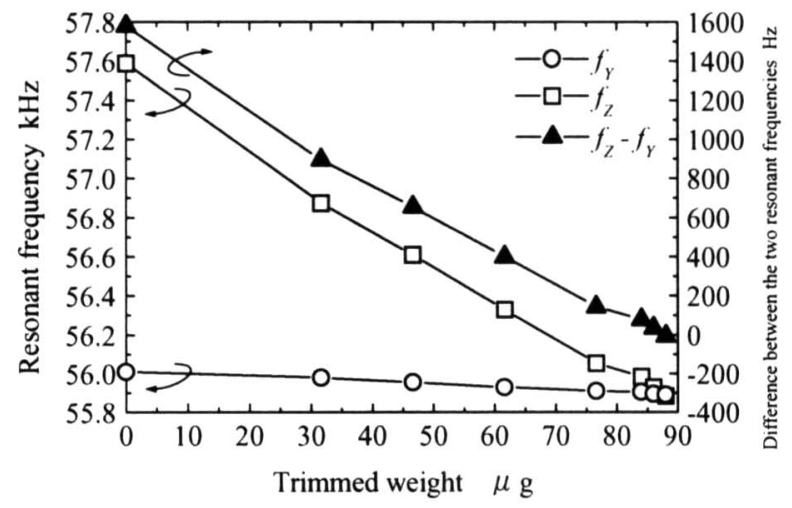

Fig.9 Change of the resonant frequency by the YAG-laser trimming

\section{であることが分かる.}

\section{2 共振周波数調整前の電気的振動特性}

レーザトリミングによって共振周波数を調整する前に，イン ピーダンスアナライザにて振動はりのY軸方向の共振周波数と $\mathrm{Z}$ 軸方向の共振周波数とを測定した. 図 8 は, 図 5 の結線(a)と 結線(b)とによる振動はりのインピーダンス特性である. 横軸は 周波数, 縦軸は, 振動はりの各印加電極から見たインピーダン スおよびそのインピーダンスと印加交流信号との位相を表す. 横軸の周波数は $55 \mathrm{kHz}$ から $59 \mathrm{kHz}$ までを示し, 縦軸のインピ ーダンスは $\log$ スケールで $50 \mathrm{k} \Omega$ から $10 \mathrm{M} \Omega$ までを示し, 位相 は-180 から $180^{\circ}$ までを示す。なお，インピーダンスが極小 を示す周波数はそれぞれの軸方向における共振周波数をおおよ そ表し, 極大を示す周波数は反共振周波数をおおよそ表す ${ }^{81111}$. これより, Z 軸方向の共振周波数は, $57.590 \mathrm{kHz}$ (インピーダン ス: $57.37 \mathrm{k} \Omega$ ) であり, $\mathrm{Y}$ 軸方向の共振周波数は, $56.010 \mathrm{kHz}$ (イ ンピーダンス：170.5 k $\Omega$ )であった.この結果, レーザトリミン グによって共振周波数を調整する前の振動はりの共振周波数差 は, $1580 \mathrm{~Hz}$ であることが分かった.

\section{3 共振周波数調整後の電気的振動特性}

この振動はりにレーザトリミングを行った結果を図9に示す. 図 9 は,レーザトリミング量に対する $\mathrm{Y}$ 軸方向の共振周波数, $\mathrm{Z}$ 軸方向の共振周波数さらにそれらの共振周波数差を測定した 結果である. 共振周波数の粗調整には, レーザ出力を $3.8 \mathrm{~W}$, トリミング繰り返し回数を 1 4 回とした条件を適用した. また, 微調整には，レーザ出力を $1.0 \mathrm{~W}$ とした条件を適用した. 図 7 と同様に，レーザトリミング量を増加させるに従い， $\mathrm{Z}$ 軸方向 の共振周波数は次第に低下するが, Y 軸方向の共振周波数はほ とんど変化しないことが明らかとなった.レーザトリミングを 続けることによって, $\mathrm{Y}$ 軸方向と $\mathrm{Z}$ 軸方向との共振周波数差は

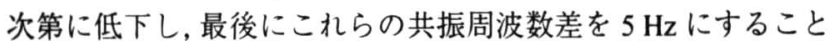

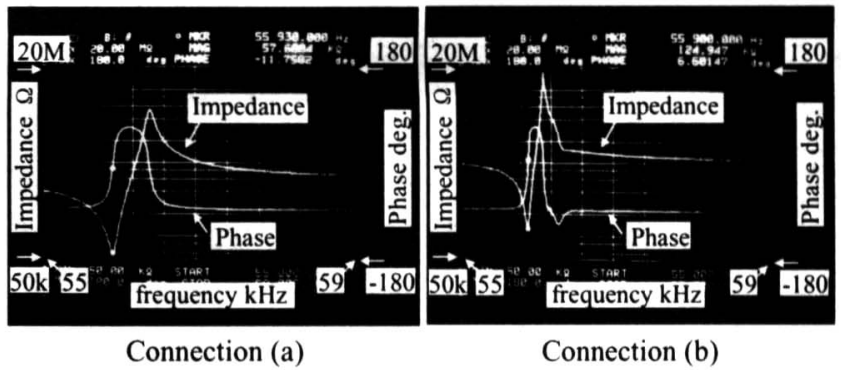

Fig.10 Impedance characteristics of the LT resonator after the YAG-laser trimming by impedance/gain-phase analyzer
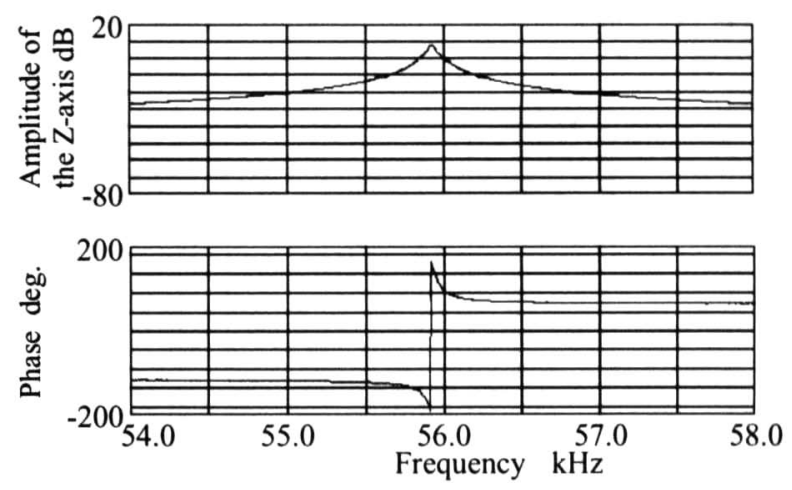

Fig.11 Vibration characteristics of the $Z$-axis
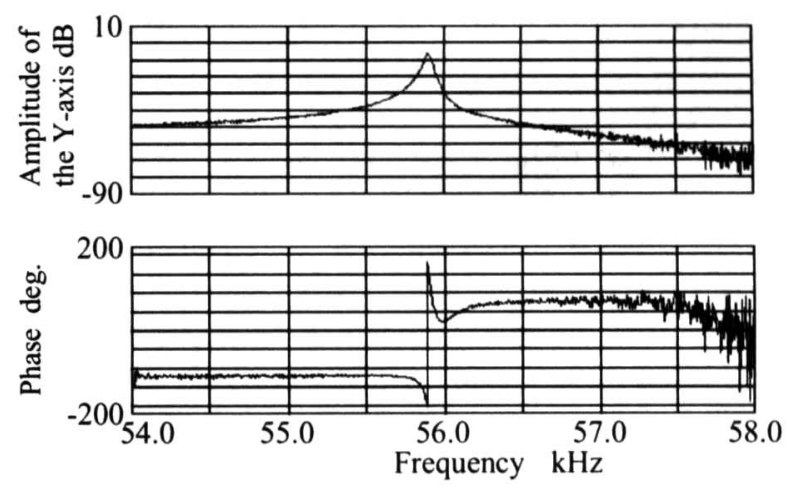

Fig.12 Vibration characteristics of the $\mathrm{Y}$-axis

ができた。このときのインピーダンスアナライザによる測定結 果を図 10 に示す.横軸㧍よび縦軸の表記は図 8 の場合と同様で ある. 図 10 より, Z 軸方向の共振周波数は $55.885 \mathrm{kHz}$ (インピ ーダンス: $58.00 \mathrm{k} \Omega$ ) であり, $\mathrm{Y}$ 軸方向の共振周波数は $55.890 \mathrm{kHz}$ (インピーダンス：121.2 k $\Omega$ )であることが分かった.これらの 值から, $\mathrm{Y}$ 軸方向の共振周波数と $\mathrm{Z}$ 軸方向の共振周波数とがお よそ一致していることが確認できる.また, 共振周波数差が $5 \mathrm{~Hz}$

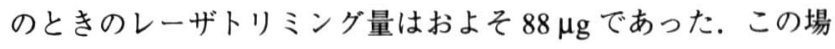
合の共振周波数差の变化率はおよそ $18.0 \mathrm{~Hz} / \mu \mathrm{g}$ であった.

\section{4 共振周波数調整後の機械的振動特性}

共振周波数調整後の振動はりの機械的な振動特性を LDVに よって評価した．図 11 は振動はりを Z 軸方向に振動させたと きの Ch1 での振幅と位相との周波数特性であり, 図 12 は Ch2 での振幅と位相との周波数特性である.ここでの振幅と位相と は, FFT アナライザからの交流信号(単位:V)に対する振動はり の振幅に対応した LDV からの出力信号 (単位:V)の比 (単 位: $\mathrm{dB}$ )とそれらの信号の位相とをそれぞれ表している.いずれ の周波数特性においても, 共振周波数を示すピークは一つしか 


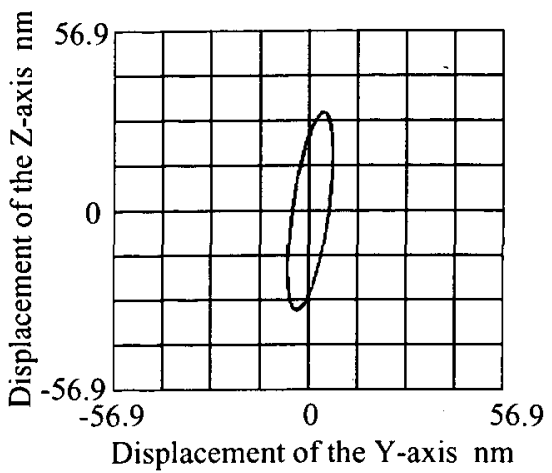

Fig.13 Vibrating locus of the LT resonator by the connection (a)

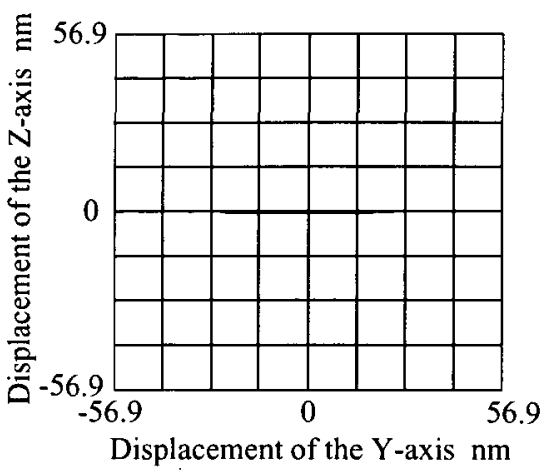

Fig.14 Vibrating locus of the LT resonator by the connection (b)

現れておらず，それらの周波数はほぼ等しいことが分かる. 図 11, 図 12 より, Y 軸方向の共振周波数は $55.895 \mathrm{kHz}$ であり, Z 軸方 向の共振周波数は $55.904 \mathrm{kHz}$ であることが分かった。これらの 共振周波数差は $9 \mathrm{~Hz}$ である。この結果は，インピーダンスアナ ライザによる測定結果とほほ等しく，そ扎ぞ扎軸方向におけ る共振周波数はほぼ一致していると言える。

さらに, 周波数が $55.904 \mathrm{kHz}$ における振動はりの振動軌跡を 測定した。そその結果を図 13 および図 14 に示す. 図 13 は結線(a) での測定結果であり，図 14 は結線(b)での測定結果である。す なわち, 図 13 は共振周波数 $55.904 \mathrm{kHz}$ にて Z 軸方向に振動は りを振動させたときの測定結果であり，図 14 は同じ周波数にて Y 軸方向に振動はりを振動させたときの測定結果である。この ときの振動角度 $\theta$ は $6.96^{\circ}$ であった。こ扎らの測定結果には，Y 軸方向の共振周波数と $\mathrm{Z}$ 軸方向の共振周波数とがほほ一致して いるにもかかわらず，メカニカルカップリングの影響が現れて いない.さらに, 周波数が $55.895 \mathrm{kHz}$ の場合においても同様の 結果を得ることができた。このような現象が生じた理由の一つ として, 振動はりの互いに直交する二つの振動モードの共振周

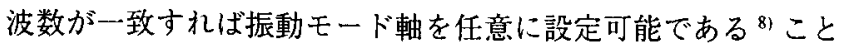
が挙げられる。つまり，振動はりの駆動モードの共振周波数と 検出モードの共振周波数とがほほ一致しているので， $\mathrm{Z}$ 軸方向 に振動はりを振動させる結線(a)では振動はりを乙軸方向に振動 させることができ，Y 軸方向に振動はりを振動させる結線(b)では, 振動はりを $\mathrm{Y}$ 軸方向に振動させることができたと考えられる。

以上のように，本実験で示したレーザトリミングによって振 動はりの各共振周波数を一致させれば，メカニカルカップリン グの影響が無く振動はりを $\mathrm{Y}$ 軸方向または Z 軸方向に共振振動
させることが可能である。

\section{4. 結論}

振動式のジャイロセンサの振動子として, 電気機械結合係数 が高い $130^{\circ}$ 回転 Y 板のリチウムタンタレートを用いた小型の バイモルフ構造の両持ち振動はり（長さ $10 \mathrm{~mm}$, 厚さ $1.014 \mathrm{~mm}$, 幅 $0.97 \mathrm{~mm}$ ）試作した. 角速度の検出感度を最大とするために, 駆動モードと検出モードとの共振周波数を一致させるすなわち 振動軸方向とコリオリ力が発生する軸方向との共振周波数を一 致させることを目的として，レーザトリミングによる共振周波 数調整を試みた。 さらに，インピーダンスアナライザおよびレ ーザドップラ振動計を用いて振動はりの振動特性を評価し，次 の結論を得た。

(1) 本報で示した箇所のレーザトリミング量を増加させるに 従い，振動軸方向の共振周波数はリニアに隇少するがコリオ リカが発生する軸方向の共振周波数はほとんど変化しない.

(2) 適切な量のレーザトリミングを行うことにより，振動軸 方向の共振周波数とコリオリ力が発生する軸方向の共振周波 数とをほほ一致させることが可能である。

(3) 振動はりの共振周波数をレーザトリミングによって調整 す札ば，メカニカルカップリングの影響が無い状態で，振動 はりを振動軸方向およびコリオリカが発生する軸方向のいず れの方向にも共振振動させることが可能である。

\section{文 献}

1) R.T. Smith and F.S. Welsh: Temperature Dependence of the Elastic, Piezoelectric, and Dielectric Constants of Lithium Tantalate and Lithium Niobate, J. Appl. Phys,, 42, 6 (1971) 2219.

2）尾上守夫, 品田敏雄, 伊東国太, 宫崎茂行: 零温度係数タンタル酸 リチウム屈曲振動子，信学技報，US73-16, (1973) 1.

3) 若月 界, 小野正明, 山田澄夫, 高橋芳孝, 山内 基, 菊池一二: $\mathrm{LiTaO}_{3}$ 単結晶音さ振動子を用いた圧電ジャイロ, 信学技報, EMD94-66 (1995) 27.

4) 小野正明, 若月 升, 高橋芳孝: $\mathrm{LiTaO}_{3}$ 単結晶を用いた音さ形圧電 ジャイロ，電子情報通信学会論文誌，J79-C-II， 11 (1996) 610.

5) K. Maenaka and T. Shiozawa: Silicon Rate Sensor Using Anisotropic Etching Technology, Tech. Digest Transducers'93, (1993) 642.

6) M. Yamashita, K. Minami and M. Esashi: A Silicon Micromachined Resonant Angular Rate Sensor Using Electrostatic Excitation and Capacitive Detection, Tech. Digest of the 14th Sensor Symp., (1996) 39.

7) 持田洋一, 杉本正一, 森屋和文, 長谷川友保, 厚地健一, 田中克彦, 大和田邦樹：振動型マイクロジャイロの基礎特性、日本機械学会 ロボティクスメカトロニクス講演会'95 講演論文集, A, 95-17 (1995) 406.

8) 阿部 洋, 吉田哲男, 中村僖良: 圧電セラミック円柱形振動ジャイロ の振動モード解析, 電子情報通信学会論文誌, J78-C- I , 11 (1995) 567.

9) K. Maenaka, T. Fujita, Y. Konishi and M. Maeda: Analysis of a Highly Sensitive Silicon Gyroscope with Cantilever Beam as Vibrating Mass, Sensors and Actuators, A, 54 (1996) 568.

10) 明石照久, 大津満雄, 長崎 正, 角田莞爾 : リチウムタンタレート 压電材料を用いた小型バイモルフ振動子の振動特性, 精密工学会誌, 67, 5 (2001) 775 .

11) 塩䇂 忠: 新・圧電材料の製造と応用, シーエムシー, (1987) 45 . 